\title{
A Merger Between Logistics Companies in the Context of the Brazilian Agribusiness: Rumo (Cosan) and All (Latin America Logistics)
}

\author{
Rodrigo Duarte Soliani ${ }^{1}$, Mauro Vivaldini ${ }^{1} \&$ Samuel da Silva Neto ${ }^{2}$ \\ ${ }^{1}$ Business and Management Department, Methodist University of Piracicaba, Piracicaba, Brazil \\ ${ }^{2}$ Logistic System EngineeringDepartment, University of São Paulo, São Paulo, Brazil \\ Correspondence: Rodrigo Duarte Soliani, Business and Management Department, Methodist University of \\ Piracicaba, Piracicaba, 13.400-760, Brazil. Tel: 5519-998-419-851. E-mail: rdsoliani@hotmail.com
}

Received: October 11, 2015

Accepted: October 26, 2015

Online Published: October 28, 2015

doi:10.5539/emr.v5n1p1

URL: http://dx.doi.org/10.5539/emr.v5n1p1

\begin{abstract}
Railway transport is not only a public utility service, but also, when analyzing agribusiness, it is decisive in relation to the efficiency of Brazilian commodities to gain competitiveness against the competitors from international markets. Thus, recently the logistics and agribusiness market were spectators of the merger between RUMO (branch of Cosan) and ALL (América Latina Logística). On the representativeness of these companies, both in the transport sector, as in the agro-industrial sector, this paper aims to analyze factors preceding the merger and thus diagnose determinants further objective is to investigate what the potential consequences of such restructuring in the Brazilian railway market.
\end{abstract}

Keywords: merger, railway transport, agribusiness, competitiveness

\section{Introduction}

The Brazilian agricultural market, especially if addressing the production of commodities, is extremely competitive, both internally and within the foreign market, given the fact that in both situations the producer is a price taker in the market, as the prices abroad are set in stock markets, which exhibit conducts rated by supply and demand characteristics of each product.

According to the context of perfect competition, cost minimization is a key factor when it aims to maximize the economic gains of Brazilian producers. To scale the importance of logistics in the Brazilian economic scenario, as reported by ILOS (2014), it is estimated that Brazil has expenditures of approximately $11.5 \%$ of Gross Domestic Product (GDP) on logistics.In this context, in recent years, logistics operators, train concessionaries, transporters and other institutions related to cargo transportation in Brazil are becoming increasingly important, after all, when analyzing agribusiness, they are the main tools for producers to minimize their logistics costs and consequently increase their competitiveness on the international market.

Recently, the largest independent logistics company in Latin America, ALL, had a significant portion of their equity assets acquired by Cosan group, which operates since 2011 as a logistics operator by transhipment of cargo and transporting products through railways.

According to Silva Neto and Rocha (2014), in the case of soybeans produced in Mato Grosso with the Port of Santos as the final destination, the share of road transport in relation to producer income reaches $24 \%$. So, in order that the sector's competitiveness is maximized against the international market, alternative modes of transportation, such as the railways, should be set in ascending order.

Considering the representativeness of those involved in such acquisition, and the influence that the railway sector has in other sectors of the economy, after all, it is public service (ANTT, 2015), it is necessary to analyze the potential consequences of such change in the market.Therefore, this article aims to diagnose the potential consequences of such a merger, focusing on the transportation of agricultural loads, investigating whether it will create a private monopoly from public goods and so affect the competitiveness of logistics and agribusiness sectors. 
The adopted research technique is the literature review. According to Pizzani (2012) "the literature review is an essential step before designing or developing a study, article, thesis or dissertation". A bibliographical research was conducted in theses, dissertations, articles, newspapers and industry magazines and was used to justify the importance of the themes explored, and provide theoretical tools to support relevant results. In addition, the main source of information pertaining to the results of this study were the opinions released by the Administrative Council for Economic Defense (CADE) about the acquisition analyzed.

This paper will present a literature review in the context of corporate mergers and acquisitions, as well as presenting relevant characteristics of the Brazilian railway transportation system. So that the results are properly stated, it is necessary the presentation of three assumptions, they are:

a) RUMO and ALL are companies operating at different levels within the supply chain, which are respectively, logistics operator and railway concessionaire, so the merger between the two should be considered vertical;

b) Given the specificities of the assets involved in the provision of rail services, it is understood that transaction costs between the service contractor and the contractor are too high, consequently, such a chain tends to integrate in a vertical form;

c) The Brazilian railways, even after privatization through concession model in the $1990 \mathrm{~s}$, is in need of investment, mainly towards the improvement and expansion of the railway network. The investment potential apart from the concession contract, which will potentially resulting from the merger between RUMO and ALL, will bring benefits to all sectors that dependent of railways services.

\section{Mergers and Acquisitions}

According to Wright, Kroll and Parnell (2000) a merger is the creation of a new organization coming from the union between two or more organizations. In that way, for the new institution to achieve its objectives and establishes its rights and duties, the consolidation of new entrepreneurial goals is required.

Reed and Lajoux (1998) present acquisition as the change in the composition of corporate society of the target business, according to the authors, the fundamental difference between acquisition and merger is the merger may or may not be achieved after the acquisition.

In this context, Camargos and Barbosa (2009) state that the M \& A strategies in Brazilian society, in general, provide operational synergies to the targeted business strategies while maximizing the market value of the same and profitability of shareholders.

According to Gartner (2004) and apud Silva (2013), the acquisitions and mergers can be distinguished between horizontal, which occur when the companies involved produce equivalent goods or services to one another; vertical, when the companies involved are located at different levels in the supply chain sector and conglomerates, in which any relations are involved between previous activities to action.

According to Williamson $(1985,1989)$, the specificity of the assets of a particular company is the main factor that influences the transaction costs, on the other hand, transaction cost is defined as the system operating cost (Arrow, 1969 cited by Williamson, 1985).

In this sense, according to Williamson $(1975,1985)$, transaction costs are exemplified by costs involved in ensuring compliance with contracts, which may be linked to the negotiation, preparation and collection of the agreements.Besides that, according to the author, when the probability of opportunism is high, uncertainty is high and there is the presence of assets with a high degree of specificity, it is encouraged to full vertical integration, meaning when the company operates in more than one stage of production chain of a good or service.

Therefore, this chapter presents the characteristics relevant to the processes of mergers and acquisitions corporative, as such particularities are useful in terms of understanding the case.

\section{Overview of the Brazilian Rail System}

The railways, as it is described by Ballou (2011), is basically characterized as a long-haul transport and low speed for raw materials and manufactured goods at low cost. In Brazil, can be cited as an example of products handled by this modal, minerals (iron and manganese), coal and cereal grains transported in bulk (sugar, soy). In European countries, rail has a broader aspect of logistics flows, and for the transport of rail containers and rail transport of road semi-trailers.

The rail transportation runs on two forms of service, regular and private carrier, according to Ballou (2011), the regular carrier sells its services to any user, being regulated in economic and security terms by the government, 
while the private carrier belong to any particular user who handles exclusively.

Ballou (2011) concludes that despite having high fixed costs in equipment, terminals and railways, its variable cost is low, making it lower than road transport. Due to lack of infrastructure and investment in the sector throughout history, one of the reasons that points Benatto (2009), rail hasn't been widely in Brazil yet.

However, the DNIT (2014) points out that currently the railway system ranks second in Brazil as the most widely used modal and is the largest terrestrial carrying capacity standing out on road transportation, but due to lack of infrastructure and incentive from the government in the past, has made the railway network in Brazil to be privatized.

Over $96 \%$ of the rail networks operate by concessions from the government, made through a privatization program of the federal railway system in 1996. According to Pudo (2006), before the adoption of the privatizations program, RFFSA operated a total of 12 rail systems, with approximately $22,000 \mathrm{~km}$ of roads spread over 19 states, 1.400 locomotives, 37.000 wagons, a workforce comprised 40,500 employees, a system carrying 86 million tons per year. These 12 systems were organized in six networks: (a) Estrada de Ferro Tereza Cristina, (b) The Central East Loop, (c) The Northeastern Network, (d) The West Network, (e) The Southwest Network and (f) The South Network. In March 1996, the West Network (covering parts of the states of São Paulo \& Mato Grosso do Sul) was the first to be privatized. In 1997, the last stage of the privatization program was completed with the granting of rights to explore the Northeast Network (covering the states of Maranhao, Piaui, Ceara, Rio Grande do Norte, Paraiba, Pernambuco, \& Alagoas).

The privatization of each of the six rails netwok was coordinated by BNDES, by granting the right to exploit the rail network for 30 years (to be renewed by mutual agreement with the Granting Authority for an additional period of 30 years). In addition, the licensee obtained the right to use the main assets required for the operation of these rail networks through leases of assets from the lease payments to RFFSA.

After the privatization, according to PUC-Rio (2015), most Brazilian railway concessions came under the control of three groups. The first is the CVRD, the largest producer and exporter of ore pellets, and one of the world's leading producers of manganese and ferroalloys. CVRD controls the Estrada de Ferro dos Carajás and Estrada de Ferro Vitória-Minas, linking producing regions ore Carajás and Minas Gerais to São Luís ports and Tubarão, respectively. The second group is formed by CVRD, Previ (Pension Fund of the Brazil Bank staff) and FUNCEF (Foundation of Federal Economists), two of the largest Brazilian pension funds, the LAIF (Latin American Investment Fund) and JP Morgan Partners. This group held the concession to operate the networks Midwest and the State of São Paulo, operating through Ferrovia Novoeste, Ferrovia Norte Brazil (Ferronorte) and Ferrovia Bandeirantes (Ferroban), except for the area operated by ALL, one of the companies focus of this study. Until the acquisition of Brazil Ferrovias and Novoeste, ALL represented the third main holder of rail concessions in Brazil, operating mainly in the South and Southwest regions. Upon completion of the acquisition, ALL became the main holder of rail concessions in Brazil.

\section{Rail Transportation of Agricultural Cargo}

As shown in Figure 1, obtained through SIFRECA and CEPEA data (2015), during the year 2014, the commitment of the revenue from sugar producing regions of Pradópolis and Igarapava, located in the state of São Paulo, with the road freight reached the $14 \%$ level.

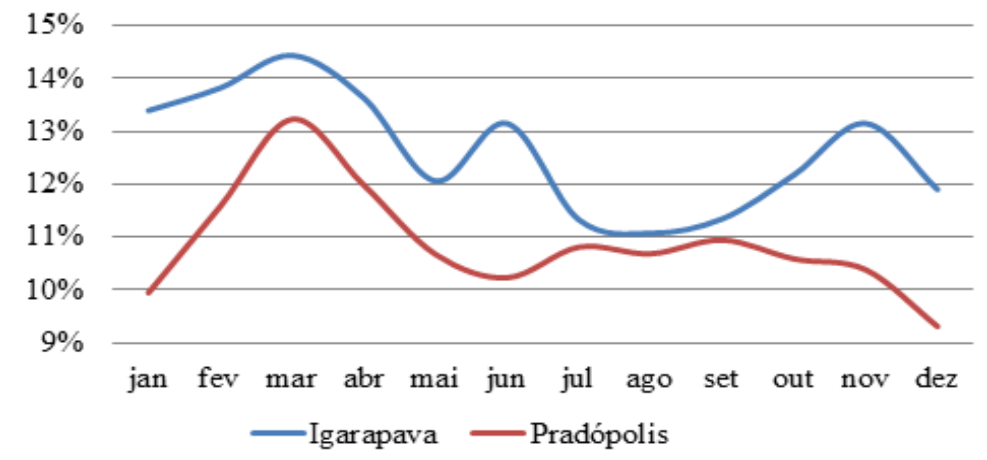

Figure 1. Sugar producer's revenue commitment from road transportation

Source: CEPEA e SIFRECA, 2015 
In addition, the chart also explains that sugar producers are vulnerable to seasonal price of road freight, which makes the logistics planning of medium and long-term more difficult. For soybeans, the share of transport in producer income and seasonal variations are even greater, as can be seen in Figure 2.

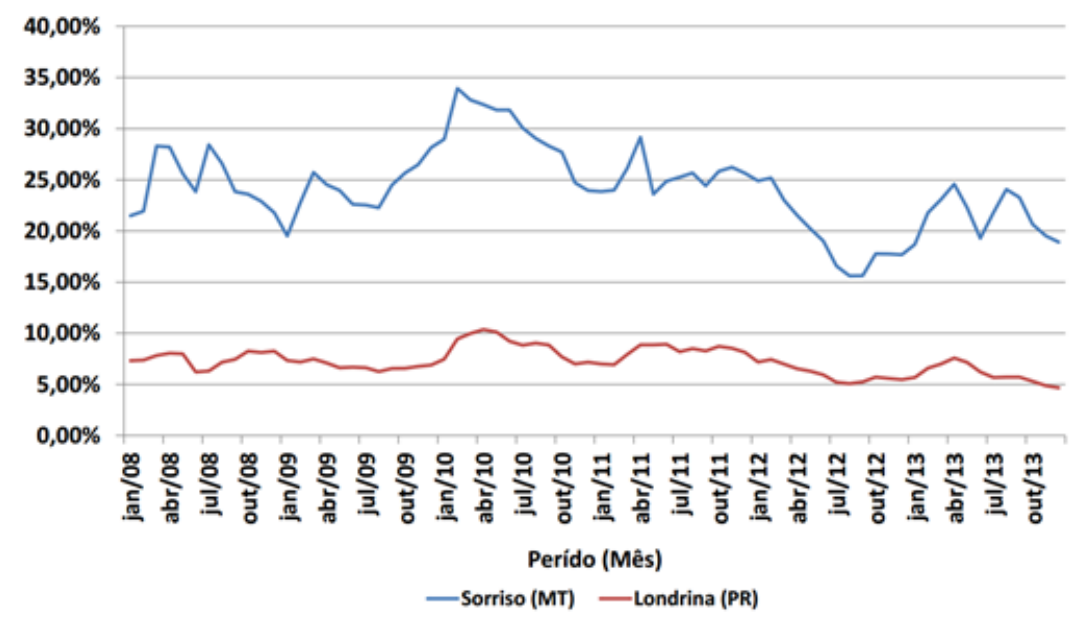

Figure 2. Road transportation impact on soybean prices in Sorriso and Londrina

Source: Silva Neto e Rocha, 2014

The usage of modal alternatives, such as the railways, has gained importance when it comes to minimizing the agribusiness transportation costs and consequently maximize the competitiveness of the sector front the international markets. According to Venkovisk (2011), the period after 2006 is characterized by the railroad advance driven by the transport of products from the agribusiness.

According to Silveira (2012), the fundamental concern of the government with the implementation of the railway concession model in the 90s was to get rid of the damage left by the national railways to public coffers, however, according to the author, such concessions are characterized as simple and full of flaws. In this way, the results of the concession model were far short of what was expected, after all, the scrapping of the network and railcars remains in evidence, investments are scarce, targeting long-term financial returns and regional development was left behind.

The concessionaires that manage most of the Brazilian rail network are shown in Table 1, especially the America Latina Logistica, which, adding their four networks granted by the state, totaling 12,000 kilometers in length.

Table 1. Brazilian railway concessionaires

\begin{tabular}{lcc}
\hline \multicolumn{1}{c}{ operator regulated by antt } & abbreviation & rail length (km) \\
\hline américa latina logística malha norte s.a. & allmn & 754 \\
américa latina logística malha oeste s.a. & allmo & 1.945 \\
américa latina logística malha paulista s.a. & allmp & 1.989 \\
américa latina logística malha sul s.a. & allms & 7.265 \\
estrada de ferro carajás & efc & 892 \\
estrada de ferro paraná oeste s.a. & ferroeste & 248 \\
estrada de ferro vitória a minas & efvm & 905 \\
ferrovia centro-atlântica s.a. & fca & 7.427 \\
valec/subconcessão: ferrovia norte-sul & fns & 720 \\
ferrovia tereza cristina s.a. & $\mathrm{ftc}$ & 164 \\
mrs logística s.a. & $\mathrm{mrs}$ & 1.674 \\
transnordestina logística s.a. & tlsa & 4.207 \\
\hline Sour ANTT, 2015 & &
\end{tabular}

Source: ANTT, 2015 
However, for rail transportation has a effective use, consideration should be given to road and rail logistics solution. According to Nunes (2011), the logistics solution is the sum of expenses incurred for a multimodal transport operation: road freight, cost of transshipment and rail freight. This concept is used to enable the comparison of the competitiveness of railways against the road competing alternative, as seen in Figure 3.

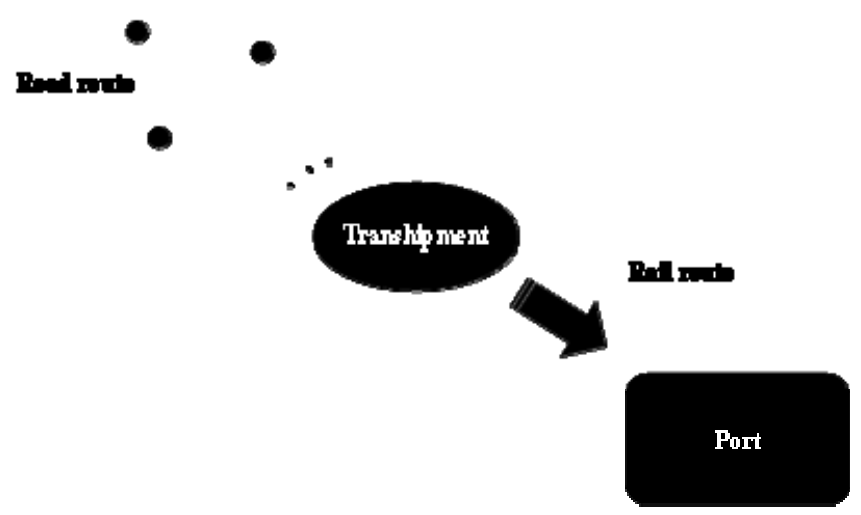

Figure 3. Logistics solution

Source: Silva-Neto, 2014

According to Silva-Neto (2014), the first item of the logistics solution is the road freight, which refers to the amount paid by the producers for the carrier to transport sugar from mills to the transshipment point.Transhipment is characterized as the operation performed to remove the sugar from the trucks, store and put it inside the railcar. The agent receiving the payment is the company responsible for the transshipment terminal. Rail freight is the amount paid by the mill to the railway concessionaire, it is characterized as the railway service from the transshipment point to the unloading terminal located at the port.

\section{Results and Discussion}

\subsection{Companies Involved in the Merger}

The companies involved in the merger are Latin America Logistics and Rumo Logística (logistical branch of Cosan), the relationship between the two companies began in 2009 when a railway contract was signed. The contract established investments from RUMO in the rail network of ALL of approximately 1.2 billion reais, and in return, ALL should ensure the transportation of sugar originated in RUMO's transhipment terminals in the state of São Paulo, to the Port of Santos.However, Cosan said that the share prescribed on the contract due to ALL was not honored and therefore, negotiations began to take place in dispute as of October 2013 (ÉPOCA NEGÓCIOS, 2014).

In a statement issued on 2015.3.2, the new company formed by RUMO and ALL announced its new executive composition, as the presidency of the new company was taken over by Julio Fontana Neto (formerly managing director of Logistics Cosan). Also according to this statement, the new company will have two operating fronts, one ahead of São Paulo and northern grids, which will be led by Daniel Rockenbach (formerly CEO of Rumo) and regarding the southern and western grids area operations, it will be led by Darlan Fabio De David (formerly director of ALL), both became operational vice presidents (EXAME, 2015).

\subsection{América Latina Logística (ALL)}

ALL Rail Operations consists of four rail concessions in Brazil, totaling 12,900 km of railways, about 1,000 locomotives and 27,000 wagons, through which the company transports agricultural commodities and industrial products (ALL, 2015). The four concessions are described in the following paragraphs, moreover, they are displayed on the map of Figure 4.

a) ALL — South Network: ALL southern network concessionaire connects the states of Rio Grande do Sul, Santa Catarina and Paraná, to their ports, they are: Rio Grande; São Francisco do Sul and Paranaguá. In addition, the same network also promotes the interconnection of the transhipment terminals localted in the south area of the state of São Paulo to the south of the country, so using the transshipment terminal located in Ourinhos (ALL, 2015). 
b) ALL_West Network: connects the Mato Grosso do Sul state to the state of São Paulo, and further, through the São Paulo network provides access to the Port of Santos (ALL, 2015).

c) ALL-North Network: section that connects the state of Mato Grosso to the city of Santa Fé do Sul-SP. Nowadays the grid connects to the city of Rondonópolis-MT, important hub center grain in midwestern Brazil (ALL, 2015), considering that according to data from Conab (2015), the city has the second largest grain storage capacity in Brazil.

d) ALL-São Paulo Network: it links important production centers in the state of São Paulo with the Ports of Santos region, the São Paulo network enables, through integration with other meshes, the flow of products from the states of the Midwest (ALL, 2015).

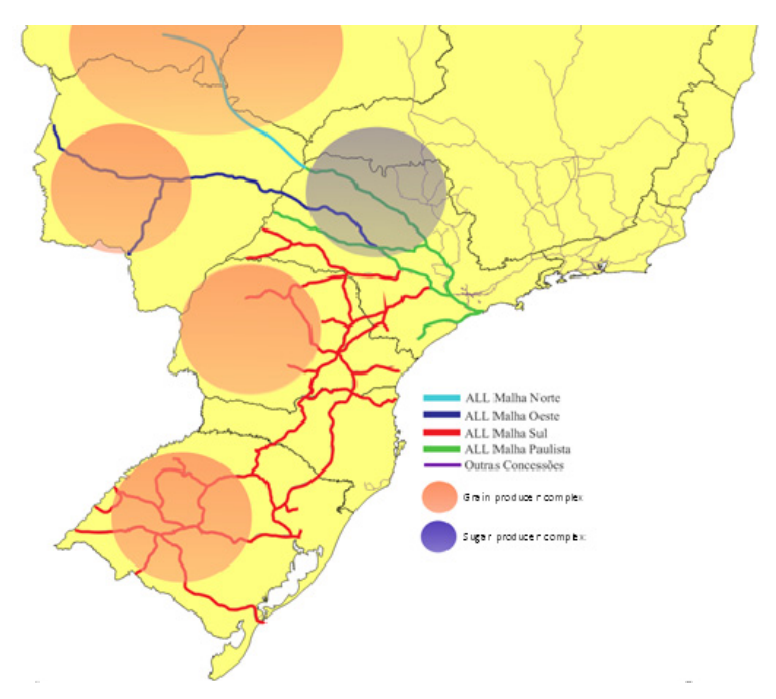

Figure 4. ALL Concessions and production centers of grain and sugar (2014)

Source: Elaborated by the authors from data of ANTT and IBGE, 2015

\section{$5.3 R U M O$}

RUMO was created in 2008 by the Cosan Group, it is considered the world's largest player in sugar export logistics. It was stablished with thought and investments aimed at changing the current situation in the logistics of sugar and other bulk cargo for export at the Port of Santos: replace the current road logistics by the railway logistics. In addition to the multimodal transport service and storage products, the company has terminals in the Port of Santos, enabling them to carry the loads from the production centers to their own port terminals (RUMO, 2015).

With the merger of the port terminals of sugar Cosan Portuária and Teaçu in 2008, the company currently has a loading capacity of 10 million tons of sugar and other dry bulk cargoes, plus a static capacity of 380,000 tons of bulk sugar and 55,000 tons of bagged sugar. These numbers make itthe largest port facility specialized in operating sugar in the world (RUMO, 2015). Figure 5 shows an aerial image of the site. 


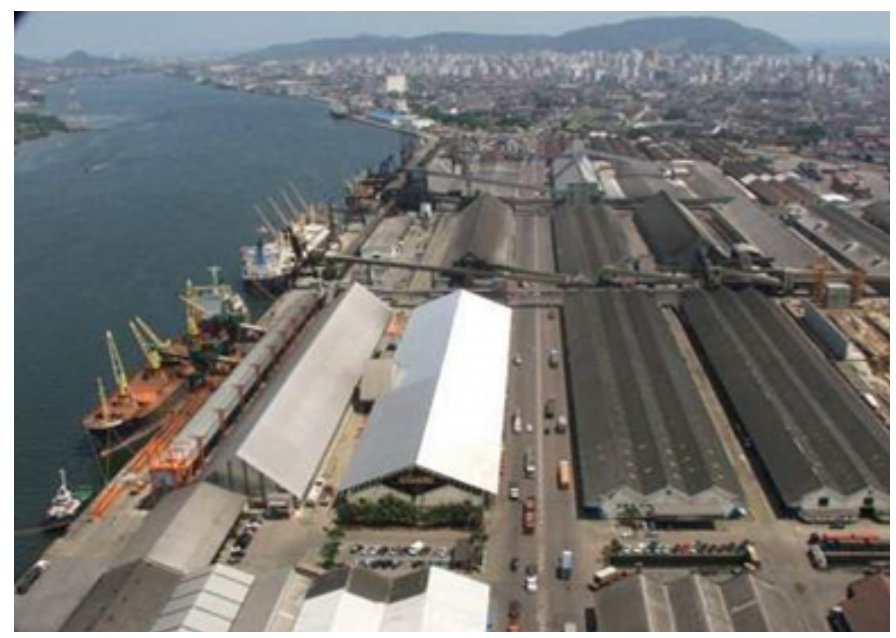

Figure 5. Terminal RUMO

Source: RUMO (2015)

RUMO has a strategy of cargo centralization in their intermodal terminals, which are located close to the mills. They carry the product at the mills with trucks and unload in transhipment terminals, to be disposed to Santos via railroad.According to Oliveira and Caixeta-Filho (2007), there is room for increasing the participation of the railway mode, which is, in practical terms, what is seeking the companies that use this strategy.

Besides the port terminal, RUMO has seven intermodal terminals along the state of São Paulo. Figure 6 shows their arrangement in the state of São Paulo.

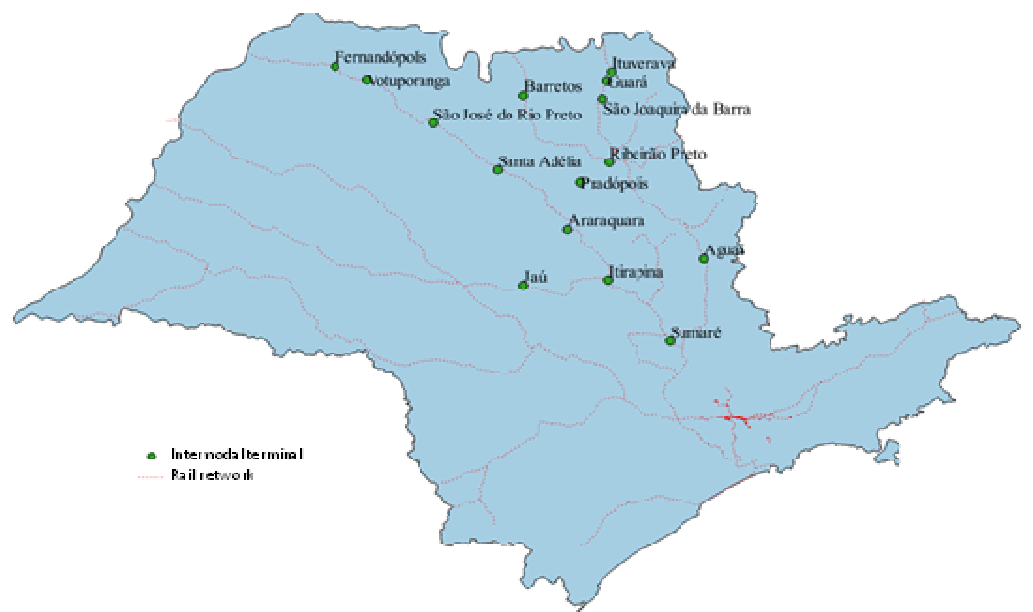

Figure 6. Location of RUMO's rail transhipment terminals

Source: RUMO (2015)

In addition to the investments already mentioned above, according to Brito (2012), the company is studying an unprecedented coverage project of the their terminal at the Port of Santos, which comes as an important logistics solution for the lack of operation on rainy days. This problem causes the interruption of the operation, on average, approximately 90 days per year.

In Barretos and Votuporanga terminals, RUMO works with third parties and handles, in addition to the load produced by Cosan, sugar originated from third-party.The Itirapina terminal was newly opened and so does not have a good statistical history data movement. 


\subsection{Merge Impacts in Transportation and Agribusiness Sectors}

According to the Concentration Act No. 08700.005719/2014-65, prepared as opinion given by Administrative Council for Economic Defense (CADE), three were the agents who formally expressed against the merger of RUMO and ALL, they are: 1) Brazilian Association the Vegetable Oil Industry (ABIOVE); 2) Agrovia Brazil, operating in the transportation sector and commodities elevation in the south-central and northeastern areas of Brazil; and 3) Federation of the State of Paraná Agriculture (FAEP).

According to the opinion, ABIOVE states that the operation has a potential privilege to sugar transport over the transport of grain. AGROVIA and FAEP point out in their line of argument to the potential discrimination of contracts and prices in the sugar market and the logistics market in general.Given this line of thinking, CADE states that this line of argument is unfounded, noting that such potential strategies has no justification ruled in the economic viability.

CADE points out that discrimination does not occur by a number of factors, the most representative are: 1) 70\% of the sugar volume operated in the Port of Santos has been transported by road transportation; 2) Only part of the rail volume of sugar that disembarks in the Port of Santos comes from the rail network of ALL; 3) The competitiveness of railways in relation to the sugar boarding is limited, as there is little difference between the imputed logistics costs in railways and road transportation for sugar; 4) the profits of the new company with the grain transportation is significantly higher when compared to the transport of sugar.

The last point deserves special mention, after all, comes directly from economic viability around the potential performance of the new company from the merger. Therefore, CADE report back the comparative distances practiced in the transport of grains and sugar in 2013 through the ALL São Paulo network. This comparison can be seen in Table 2.

Table 2. Comparison of sugar and grain transported on the railway in 2013

\begin{tabular}{lccc}
\hline \multicolumn{1}{c}{ Product } & Total cargo handled (ton) & Tons per kilometer (TKU) & Average distance (km) \\
\hline Sugar & 2.890 .728 & 1.178 .200 .082 & 407,60 \\
Soy & 4.480 .637 & 6.399 .061 .906 & $1.428,20$ \\
Corn & 6.576 .884 & 10.016 .457 .990 & $1.523,00$ \\
Soy chaff & 1.918 .625 & 2.666 .428 .364 & $1.389,80$ \\
\hline
\end{tabular}

Source: CADE aput Caixeta Filho, 2014

Also in this sense, Silva-Neto (2014) concludes by Figure 7, that as far as the average distance of the sugar's rail movement, grains, soybeans, corn and soybean meal are more attractive for railway concessionaires. Therefore, in periods of high grain flow levels, sugar tends to suffer from low levels of railcars and trucks available for immediate shipping. 


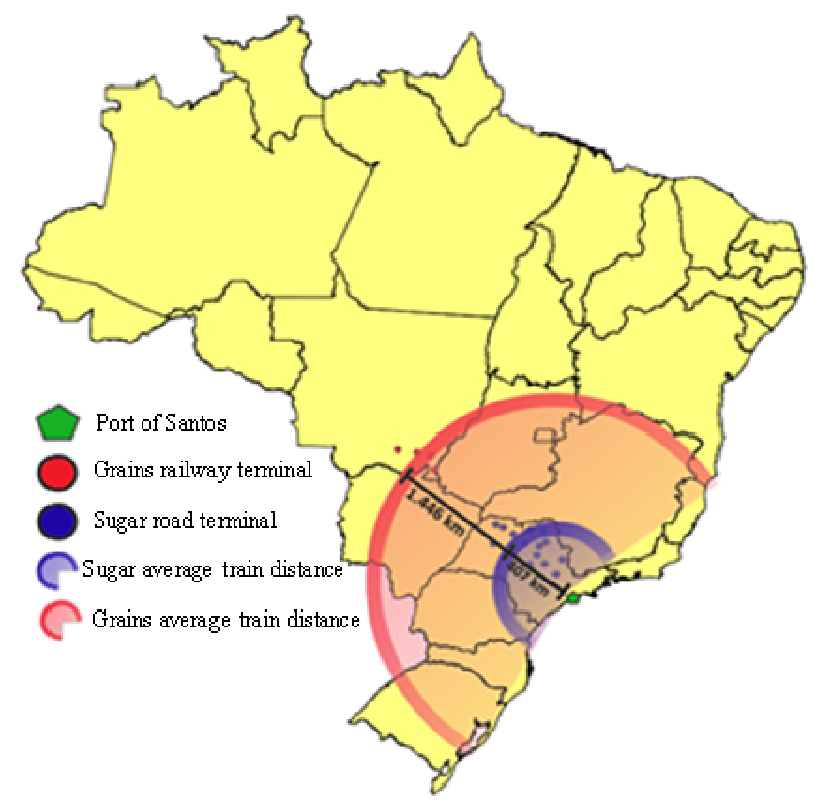

Figure 7. Average distances of railway operations headed to the Port of Santos in 2013 Source: Silva-Neto (2014)

Another argument that, according to FAEP (Support Foundation to Research and Education), would bring economic risks to the national logistics scenario is the vertical integration between RUMO and ALL, which would take place because RUMO have a extensive port infrastructure and ALL the railway infrastructure. For this demonstration CADE argues that operations which generate vertical integrations are generally less likely to create anti competitive effects, compared to horizontal mergers, these effects further reduced when dealing with only partial integration.

Even facing the claims presented by the agents mentioned in the previous paragraphs, CADE approved on 02.11.2015 the merger between the companies analyzed here, however, it is worth highlighting some requirements related to company performance, they are: 1) COSAN will have a limited usage of the ALL infrastructure; 2) In the case of idleness of the railway system, competitors will have priority in the use, and only if there is no interest, such idleness will be offered to Cosan; 3) CADE has created a formula for fixing the railway tariffs of the grid, so that competitors can identify if they are paying prices beyond or below the prices paid by Cosan; 4) The company will have to give to competitors $40 \%$ of the total use of two of their terminals in Santos; and 5) There is possibility of expanding the fine and to reduce Cosan transport quota if identified the practice of price discrimination (GLOBO, 2015).

Without any doubt, what draws more attention regarding to the benefits arising from the merger between ROAD and ALL is the obligation of investment of nearly 8 Billions of reais that the new company will have to make by 2020 on improvements and duplication of the railway network in the State São Paulo, specially on parts which prevent the expansion of the railway flow to the Port of Santos (APLA, 2015).

\section{Conclusion}

After 19 years, it is already possible to see the important results of the privatization of the Brazilian rail network for freight transportation in the country. The entry of private capital in railroads caused a significant increase in investments. From 1997 until 2013, according to the ANTF (2013), it was invested by the concessionaires over $\mathrm{R} \$ 35$ billion in equipments and network improvements. According to SNA (2014), it also stimulated a 94\% increase in cargo handling; $119 \%$ growth of rail production; $173 \%$ increase in the number of employees and $69 \%$ reduction in the number of accidents.

It is undeniable that the operation of the utilities has brought improvements in several areas, such as increased productivity, and, according to the Rumo Logística's President, Julio Fontana, Revista Globo Rural (2012), it will also reduce the flow of about 30,000 trucks/day on the roads. However, there is much to improve. For the future, the development of the railways depends on a set of various factors such as expansion of the network, 
regulations, environment, technology, safety, taxation, among others.

In this study it was verified that failure to meet certain commitments set out in the agreement between ALL and RUMO triggered a range of obstacles, many of them legal. In this way, given the need to minimize these transaction costs, the strategy adopted by stakeholders was to vertically merge the companies, as the first one holds the concession of the railway and the second has transshipment infrastructure either within the state of São Paulo, as in the Port of Santos.

Furthermore, it was clear the concern on the part of agents linked to the railway transportation and grain producers associations about the possible effects of the merger.Such concerns, in general, were constituted around the potential discrimination related to transportation tariff prices, since the same company owns the railroad and also has a representative volume of sugar destined for the foreign market. Therefore we can conclude that privileging sugar transportation over the grain transportation would be a reverse economy, as it would be much more worthwhile for the railway concessionarie transporting grain than sugar, after all, both the volume and the distance are greater. Despite this fact, CADE, in their opinion, highlights a number of requirements which guarantees non-discrimination of customers and prices by the new company originated from merger between ALL and RUMO.

Therefore, we conclude that the merger will help to increase the share of the railway in the Brazilian matrix of cargo transportation, from the recovery of capacity to invest in railways, through approximately $\mathrm{R} \$ 8$ billion to be invested in the expansion and duplication of the railway network.

\section{References}

América Latina Logística (ALL). (2015). Retrieved from http://www.all-logistica.com/port/index.htm

Associação Nacional Dos Transportadores Ferroviários (ANTF). (2013). As Concessionárias Do Transporte Ferroviário De Carga..

Retrieved

from

http://www.Desenvolvimento.Gov.Br/Arquivos/Dwnl_1375733867.Pdf

ANTT_Agência Nacional De Transportes Terrestres. (2015). Evolução Do Transporte Ferroviário. Retrieved from http://www.Antt.Gov.Br/

Apla. (2015). Nova All Terá Que Investir 8 Bilhões Até 2020. Retrieved from http://www.Apla.Org.Br/Nova-All-Tera-De-Investir-R-8-Bi-Ate-2020

Ballou, R. H. (2011). Logística Empresarial-Transportes, Administração De Materiais E Distribuição Física. 2. Ed. São Paulo: Atlas.

Camargos, Marcos A., Barbosa, \& Francisco V. (2009). Fusões E Aquisições De Empresas Brasileiras: Criação De Valor E Sinergia Operacional. Revista De Administração De Empresas, 49(2), 206-220. http://dx.doi.org/10.1590/S0034-75902009000200007

Cepea. (2015). Centro De Estudos Avançados Em Economia Aplicada. Retrieved from http://Cepea.Esalq.Usp.Br/

Cosan. (2015). Negócios. Retrieved from http://Cosan.Com.Br/

Da, S., Cristiano, M. (2013). Fusões E Aquisições De Empresas No Polo Dinâmico Da Economia Brasileira. Reverte-Revista De Estudos E Reflexões Tecnológicas Da Faculdade De Indaiatuba.

Departamento Nacional De Infraestrutura De Transportes. (2014). Sistema Viário Nacional. Retrieved from http://Www.Dnit.Gov.Br/Sistema-Nacional-De-Viacao/Capa-Snv

Dowell, Maria, C. M., Cavalcanti, \& José, C. (1998). Integração Vertical: Um Painel Da Literatura. Revista Nova Economia, Belo Horizonte.

Época Negócios. (2015). Os Segredos Da Fusão Rumo $E$ All. Retrieved from http://Epocanegocios.Globo.Com/Informacao/Resultados/Noticia/2014/08/Os-Segredos-Da-Fusao-Rumo-A 11.Html

Exame. (2015). Cosan, All E Rumo Reestruturam Diretorias. Retrieved from http://Exame.Abril.Com.Br/Negocios/Noticias/Cosan-All-E-Rumo-Reestruturam-Diretorias

Globo. (2015). Cade Aprova Com Restrições A Fusão Entre All E Rumo Logística. Retrieved from http://G1.Globo.Com/Economia/Negocios/Noticia/2015/02/Cade-Aprova-Com-Restricao-Fusao-Entre-AllE-Rumo-Logistica.Html

Instituto Ilos. (2014). Custos Logísticos No Brasil. Retrieved from 
http://Www.Ilos.Com.Br/Ilos_2014/Wp-Content/Uploads/Panoramas/Panorama_Brochura_Custos.Pdf

Nunes, \& Priscilla, B. (2010). Caracterização Da Logística Do Sistema Agroindustrial Da Cana-De-Açúcar No Centro-Sul Do Brasil. Escola Superior De Agricultura "Luiz De Queiroz", Universidade De São Paulo, Piracicaba.

Puc-Rio. (2015). Pontifícia Universidade Católica Do Rio De Janeiro. Retrieved from http://Www.Maxwell.Vrac.Puc-Rio.Br/8766/8766_6.Pdf

Pudo, \& Ana, P. (2006). A Importância Do Transporte Ferroviário Para O Comércio Entre Os Países Do Mercosul—Brasil X Argentina. Centro Universitario Nove De Julho, São Paulo.

Reed, S. F., \& Lajoux, A. R. (1995). The Art of M \& A-A Merger Acquisition Buyout Guide. New York: Irwin.

Revista Globo Rural. (2012). Na Direção Do Futuro. Retrieved from http://Revistagloborural.Globo.Com/Revista/Common/0,Ert308122-18283,00.Html

Rocha, Fernando, V., Saes, \& Maria, S. M. (2014). Análise Das Transações Existentes Na Contratação Do Serviço De Transporte Rodoviário De Açúcar. Xvii Semead Seminários Em Administração. Retrieved from http://Sistema.Semead.Com.Br/17semead/Resultado/Trabalhospdf/302.Pdf

Rumo. (2015). Retrieved from http://Cosan.Com.Br/Pt-Br/Negocios/Logistica/Rumo

Silva-Neto, S. (2014). Delimitação E Análise Da Potencial Área De Influência Dos Terminais De Transbordo De Açúcar Do Estado De São Paulo. Escola Superior De Agricultura "Luiz De Queiroz", Universidade De São Paulo. Retrieved from http://Esalqlog.Esalq.Usp.Br/Files/Biblioteca

Silva-Neto. (2014). Impacto Do Transporte Rodoviário Na Receita Do Produtor De Soja De Paraná E Mato Grosso. Retrieved from http://Esalqlog.Esalq.Usp.Br/Biblioteca/

Silveira, \& Márcio, R. (2012). Transporte E Logística: As Ferrovias No Brasil. Geosul.

Sistema De Informações De Fretes. (2015). Retrieved from http://Log.Esalq.Usp.Br/

Sociedade Naciona De Agricultura. (2014). Programa De Ferrovias Começa A Superar Principais Indefinições. Retrieved from http://Sna.Agr.Br/Programa-De-Ferrovias-Comeca-A-Superar-Principais-Indefinicoes/

Vencovsky, V. P. (2011). Ferrovia E Logística Do Agronegócio Globalizado: Avaliação Das Políticas Públicas E Privadas Do Sistema Ferroviário Brasileiro. Instituto De Geociência Da Unicamp.

Williamson, O. E. (1989). Transaction Cost Economics. Handbook of Industrial Organization. http://dx.doi.org/10.1016/S1573-448X(89)01006-X

Wright, P., Kroll, M., Parnell, \& Jonh. (2000). Administração Estratégica. São Paulo: Atlas.

Zylbersztajn, D. (1995). Estruturas De Governança E Coordenação Do Agribusiness: Uma Aplicação Da Nova Economia Das Instituições. Universidade De São Paulo.

\section{Copyrights}

Copyright for this article is retained by the author(s), with first publication rights granted to the journal.

This is an open-access article distributed under the terms and conditions of the Creative Commons Attribution license (http://creativecommons.org/licenses/by/3.0/). 